\title{
Corporate Social Responsibility (CSR) of MNCs in Bangladesh: A Study on Nestlé Bangladesh Limited
}

\section{Md. Monsur Ali}

Lecturer, Department of Business Administration, Dhaka City College, Dhaka 1205, BANGLADESH

*Corresponding Contact:

Email: alimd.monsur@yahoo.com

DOI: https:// doi.org/10.18034/gdeb.v7i2.108

\begin{abstract}
The article CSR of MNCs in Bangladesh scrutinizes how multinational companies conduct corporate social responsibility (CSR) in Bangladesh. The purpose of the study is to observe the framework of CSR areas and contribution to those areas by the Nestlé Bangladesh Limited. It considers the structure of CSR in the business of Bangladesh, which is now globally a vital issue for the development of society. It explains the systems of adopting CSR by the MNCs in Bangladesh, we can begin to see what implications arise from the fact that CSR is a financially developed nations' concept. Developing country like Bangladesh is considered lagging behind in its understanding and adoption of CSR practices. Generally corporations do not expose their policies. This article tried to explore current practices of CSR by the leading MNC like Nestlé Bangladesh Limited which is operating its business activities proudly for the long since.
\end{abstract}

Key Words: Corporation, CSR, MNC, Nestlé Bangladesh, stakeholders, Bangladesh

\section{INTRODUCTION}

The term corporate social responsibility (CSR) refers to actions and activities undertaken by private profit-making enterprises with the ostensible objective of demonstrating that they are citizens of the communities in which they operate and that they pursue goals other than maximizing their profits. Corporate social responsibility means that a corporation should be held accountable for any of its actions that affect people, their communities, and their environment (Post, Lawrence, Weber - 1999). Firms engage in CSR activities in response to demand from the public that these are responsible to all stakeholders. The nature and scope of corporate social responsibility have changed over time. This concept is comparatively new and day by day getting acceptability in all over the world. At present the financial, legal, ethical, and discretionary outlooks changed largely, now it is right time to say that all societies at all points in time have some degree of expectations that organizations would act reliably. Business is an inseparable and embedded part of human life. In addition to its economic contribution in society, business also has several other roles and responsibilities (Preston and Post, 1975; Davis and Blomstrom, 1971). Responsible conduct of business 
activities while pursuing economic gains; the social and environmental responsibilities of the business towards its stakeholders; and business's contributions that would benefit the society at large (Margolis and Walsh, 2001; Sethi, 1975). It is mandatory for companies to obey the rules which are stated by law. So, organizations have no alternative but to comply with the law of the land (Carrol, 1979). On the other hand, corporations are performing ethical responsibilities which are additional going beyond legal compliance and profit making. Ethical responsibility originates from the humanistic, religious and moral orientation of corporations (Lantos, 2001). The voluntary tasks to the society refer to the discretionary nature of obligations rooted in the altruistic principles which are not required by law. The motivation for such sense of duties arises from the reciprocal commitment of giving back to the society in exchange for profit and power that companies receive from the public.

\section{LITERATURE REVIEW}

Social responsibility is considered to include concerns for social factors and the environment. CSR is still a sprouting concept that enables corporate executives to create and relate self-determined policies to best meet the needs and demands of its stakeholders (Wise and Ali, 2009). Because of the increasing amount of expression which exists on this subject, it is appropriate to examine these reasons thoughtfully when making choices in this area (Davis, 1973). CSR is a set of practices that form a part of good management or business practices much of it is about transparency and disclosure (Hill, 2006). The literature recognizes that CSR practices differ from country to country (Adams, Hill \& Robert, 1998) and between developed and developing countries (Imam, 2000). Furthermore, the nature and patterns of CSR vary between types of industry (Gray et al., 2001). A technique commonly used in social responsibility research to measure the significance of content is to count the number of words used to describe a particular issue (Hackston and Milne, 1996). The bases of argument for CSR examine the interactions between business and society. Companies can enhance their authenticity through environmental exposure. There are many organizations that maintain CSR activity. There is an international example in the United Nations, which shaped the Global Compact initiative in 1999. The Global Compact asks for signatures from businesses across the world to be agreed about specific principles of social and environmental action. These principles include:

- To support and respect internationally proclaimed human rights;

- To avoid complicity in human rights abuses;

- To uphold freedom of association and the right to collective bargaining;

- To eliminate all forms of forced labor;

- To abolish child labor;

- To eliminate discrimination regarding business hiring and occupation;

- To support a cautionary approach to environmental challenges.

International agency Organization for Economic Cooperation and Development (OECD) puts together a set of social guidelines for international companies to follow created with the help of over thirty different nations. In 2004, the International Standards Organization (ISO) began a process to form a set of guidelines the ISO 26000. In 2005, more than 225 CSR specialists from forty-three countries and twenty-four other organizations attended the initial meeting. Their goal was to say, "aim to encourage voluntary commitment to social responsibility and lead to common guidance on concepts, definitions, and methods of 
evaluation." Very few studies focus on developing countries (e.g., Hossain et al. 2006; Porwal and Sharma, 1991) and no such study was carried out with reference to Bangladesh. Good CSR practices will enable companies to attract better quality investors and to meet better the challenges posed by increased competition for markets (Anwar, 2005). The size, profitability, and risk to be significantly and positively associated with the disclosure of social responsibility information (Suwaidan, 2004). A relationship found between firm size and corporate social responsibility (Saleh, Zulkifli \& Muhamad, 2008). CSR is a process driven by globalization, deregulation, and privatization. Proponents of CSR are keen to demonstrate that business has responsibilities beyond the production of goods, services, profit-making, and that socially responsible dealing can help to solve social and environmental problems. Such arguments further maintain, for example, that the role of business determines its responsibilities. As such, business has no social responsibility beyond compliance with the law. The critics make it more important for us to be clear on what we believe to be the business case for corporate responsibility (Bendell and Shah, 2002).

\section{ObJectives OF The Study}

- The objective of this study is to examine the CSR practices of a renowned multinational company like Nestlé Bangladesh Limited;

- To measure the level of corporate social responsibility disclosure made by the companies in Bangladesh;

- To understand the actual concept of corporate social responsibility;

- To find out the extent and the kinds of CSR practices by different organizations;

- To provide information for future research works on CSR.

\section{MNCS AND CSR}

MNC's are complex differentiated networks marked with internal heterogeneity and with the complexity of managing across globally dispersed, diverse units (Bartlett and Ghoshal, 1989). In the ordinary course of business, MNCs put no or little concern on social/environmental issues, even if they do so they may not remain to them. Companies are now anticipated to perform well in non-financial areas such as human rights, business ethics, environmental policies, corporate contributions, community development, corporate governance, and workplace issues. Some examples of CSR are safe working surroundings for employees, environmental stewardship, and contributions to community groups and charities. How MNCs meet these challenging demands for managing CSR in their global operations and what determines their choices remains less discussed. Foreign direct investment (FDI) flowing to developing countries has the prospective to make contributions to the development of local economies, including creating jobs, capacity building, and the transfer of technology. CSR is the most talking terminology in recent times among corporate world, business community, and capitalistic industry. Its practices integrate into national and international business arena and hence it is becoming one of the influential factors for market access. According to United Nations Industrial Development Organization, CSR is as economical, environmental, and social imperatives while at the same time address the expectation of shareholders and stakeholders. In recent time, there has been an acceleration of multinational corporate activity, in the era of globalization; MNCs that conduct business across national borders in many countries are no longer able to perform destructive and unethical practices under the protective radar. The corporate response has often meant an 
adoption of a new consciousness of doing business, and this is known as CSR for the long since. Multinational corporations (MNCs) can, therefore, have a positive impact in developing countries through corporate social responsibility (CSR) inventiveness spotlighting on sustainable development and cooperation with civil society. However, for many MNCs, CSR is an outcome of public pressure arising from their operations in developing countries about human rights, pollution, and labor issues. In other words, it has been a pragmatic response to consumer and civil society pressures (Raynard and Forstater, 2002).

The corporate response means an adoption of a new consciousness, and this is known as Corporate Social Responsibility (CSR) since the 1970 (Anupama and Mohan, 2006). MNCs face diverse stakeholder environments across their international operations. CSR has several implications for MNCs' management of stakeholder relations across the multiple levels and diverse contexts of its operations. Global CSR management also involves cross-border transfer and management of CSR practices, from one part of the MNC to another, as well as the management of local CSR practices matched to the local background of the supplementary units. The analysis of self-reported CSR practices in these MNCs revealed the globally managed CSR practices and their transnational management processes. The international business realm offers a challenging context an inquiry into firm's CSR and ongoing stakeholder relationship management since there are much more and diverse stakeholders of international business firms (Wood and Pasquero, 1997). The MNCs faced wider CSR expectations, and MNCs are under increasing difficulty for socially responsible actions in their global operations. The complex legitimacy issues faced by MNCs across these various political, economic, institutional and sociological environments are also discontinuous and marked with uncertainty and preclude universal corporate policies. The main reason is what may be acceptable in one country or at a time may run counter to public policies or acceptable norms elsewhere or at other times (Logsdon and Wood, 2002). The common CSR practices of Bangladesh by MNCs focus on poverty alleviation, healthcare, education, charity activities, cultural enrichment, youth development, women empowerment, patronizing sports, and music's, etc. These activities are devised to be the partners in development the responsible citizen. There are many examples of firms that have combined social responsibility with profitable business. The first outlet found on these principles, and it would be reasonable to conclude that the subsequent success of this firm ground on the philosophy of social behavior. (Sinha, 2005).

\section{CSR PRACTICES IN BANGLADESH}

The advancement of the corporate social performance model focused on three challenges to the concept of corporate social responsibility (CSR): economic responsibility, public responsibility, and social responsibility (Wartick and Cochran, 1985). They also scrutinized social issues management as a dimension of corporate social performance. Most of the businesses in Bangladesh are family oriented, small, and medium in size, and capital. These are involved in community development work in the form of charity without having any definite policy about the expenses or any motive regarding financial benefits in many instances (Mondol, 2007). It is obvious that the significance of CSR in the first-world, questions regarding the degree to which corporations operating in developing countries have CSR obligations are still to be worked out (Jamali and Mirshak, 2007). There has been increasing pressure on national and multinational corporations in Bangladesh to consider the social implications of their actions (Belal, 2001). Today, CSR in Bangladesh has gone beyond simply charity and donations, and move toward in a more organized fashion. It has become an integral part of the corporate tactic. Companies have CSR teams that devise 
specific policies, strategies, and goals for their CSR programs and set aside budgets to support them. These programs, in many cases, are based on defined social philosophy or are closely associated with the company's business expertise. Employees become the backbone of these initiatives and volunteer their time and contribute their skills, to implement them. CSR programs could range from overall development of a community to supporting specific causes like education, environment, healthcare, etc. Bangladeshi firms are to focal point on CSR not only for improving corporate governance, values, labor rights, right treatment of workers, community development and environment management, but also for modern industrialization and ensure global market access. The government of Bangladesh is going to take on an initiative to encourage CSR practices. The objective would be to persuade the businesses to carry out the citizen-like activities with the aim to reversing the perceived trend to have little commitment to society (Ataur, 2008). Some corporations are now following an increased commitment to CSR beyond just profit making and compliance with the regulation. It is true that MNCs are the pioneers of initiatives of CSR practices in Bangladesh. Now Bangladesh uncovered to global standards, it anticipate that the CSR activities in Bangladesh will continue to extend. Firms are now trying to espouse their corporate image of socially responsible and consequently persuade consumer buying decisions to goods and services marketed by them.

\section{Study Methodology}

The study is theoretical which required different data and information from the actual field. The used data for the study are actually secondary. The data collected for the study from annual reports, documents, books, newspapers, and subject related websites and research documents. Some relevant articles from various journals were also used to develop the idea about the topic. The empirical findings of MNCs' management of CSR in routine stakeholder relations, with employees, consumers, environment, and communities are presented. The case study design is adopted as a research strategy to study the CSR phenomenon in Bangladesh. Nestlé Bangladesh Limited is one of the pioneers in the relevant sector. In the initial stage of this research, comprehensive list of items identified regarding social responsibility that may disclose by companies in their reports. Sample units were selected based on the potential for information about CSR practices. Primarily annual reports of last four years and various CSR publications were used to analyze current practices in the field.

\section{LIMITATIONS}

This paper has some loopholes. During the study period, it was difficult to collect every type of information of CSR. While the present study has supplied useful information about CSR practices in Bangladesh, it has several limitations that must be acknowledged. The main negative side is no specific information about CSR, where there is information but no data like amount, areas, etc. Moreover Nestlé Bangladesh Limited practices their CSR in a specific regional area like Gazipur where its factory situated. Annual Reports analyzed did not provide detailed sector of CSR expenditure in the income statement. Top management of the organization was not so interested to present some essential data which may develop the weight of this paper. Many things were so confidential that was not entitled to access there. Researchers were unable to collect enough information due to official restrictions of this organization. The MNC does not have synchronized collaboration and does not partner with governments and nongovernment organizations substantially to address the impacts of business activities and to solve numerous social problems. To the best of knowledge very few studies was conducted in this specific area, that's why there is lack of clear guidance. 


\section{A Brief Profile of Nestle Bangladesh Limited}

Nestlé is one of the biggest food and nutrition companies founded by the Henri Nestlé (10 August $1814-7$ July 1890); a German confectioner in Vevey, Switzerland in 1866. In the food industry, Nestle is the most trusted name with high-quality products. The mission of the company is "Good Food Good Life". The mission of Nestlé drives the company to supply consumers with the most excellent tasting and most nutritious choices in a wide variety of food and beverage categories and eating occasions. The vision of creating shared value and the corporate business principles shaped the company culture and made them a reliable investors over 86 countries of the world. Today Nestle employs around 339,000 people and have factories or operations in almost all over the world.

Nestlé started its commercial operations in Bangladesh in 1994. Its total authorized capital is TK 1.5 billion, and paid-up capital is TK 1.1 billion. The only factory of this company in Bangladesh is at Sreepur of Gazipur which is $55 \mathrm{~km}$ north of Dhaka. Today Nestlé Bangladesh Ltd. is a strappingly positioned organization. The Company is endlessly growing through the policy of constant innovation, concentrating on its core competencies and its dedication to high-quality food products for the populace of Bangladesh.

\section{Products of Nestlé Bangladesh Limited}

Globally the product line of Nestlé is very bulky but at present time Nestlé producing 12 products in Bangladesh. The company believes that all foods and beverages can be pleasant and play vital role in a balanced and healthy diet and life. As a result no matter how short or long the product line may be but it make sure the same quality like other countries. The products of Nestlé Bangladesh Limited are;

- Beverage: Shad-Nescafé, Nescafé 3 in 1, Coffee Mate, Gold e-Magic Nestea, and Nesta.

- Culinary: Maggi Noodles, Shad-e-Magic, Maggi Healthy Soup, Magic Cube.

- Dairy: Nido Fortified, Nido 2+, Nido 3+, Nido Growing up Milk.

- Breakfast Cereal: Cornflex, Koko Crunch, and Huny Gold.

- Nutrition: Lectogen, Lactogen Recover, Prelactogen, NAN, All 110, BABY \& Me and Cerelac (Different flavors).

- Confectionary: Nestlé Munch Rolls.

\section{Nestlé Own Style of CSR is Creating Shared Value (CSV)}

Nestlé Bangladesh Ltd. practicing corporate social responsibility (CSR) as major areas of its business principles in addition to producing and marketing a wide range of food products. The company not only believes in manufacturing and marketing products, profit making, paying taxes and complying with state laws. A good organization also believes that it has something more to do for the humanity even more than CSR which has become a buzz word in the corporate world. "For Nestle, the terminology is CSV (Creating Shared Value) is Nestle's style of CSR to create value for shareholders and society simultaneously, in a manner that created a link to our core business strategies and operations," said by Corporate Affairs Director of Nestlé Bangladesh Limited. Nestlé always focuses on long-term, sustainable, profitable growth, and helps communities around its operation to improve their quality of life similarly. That is why; Nestlé says it Creating Shared Value rather than Corporate Social Responsibility. If we look to the company as a whole, Nestlé has three areas Nutrition, Water and Rural Development where they are working extensively as a part of CSV. 
Nutrition: Nestlé started as a nutrition company in the year 1866. After the establishment, it saved many infant lives by providing infant cereal. It is not only for the infants but also there are products for elderly citizens and infirm. Nestlé declared to become the world's leading nutrition, health, and wellness company, and since then its target is to reach as many people as possible through nutrition. Thus, Nutrition remains a source for CSV to aware people about the significance of nutrition, food value, and other nutrition characteristics.

Water: The second area of spotlight is water. Nestlé started effort in water in the year 1930 when they built the first water purification conveniences for their factories. The reason for what they are more alert on water is that the agricultural raw materials that need to produce the products depend on a reliable and expanding water supply, and water is under serious threat in different parts of the world. Nestlé has sponsored a change in global water policy because this is not just a Nestlé problem. It is a problem for the world's food deliver. So as long as we the people are not a concern for the proper and proficient use of water from their stand correspondingly, the insufficiency will create a threat for human being. That's why Nestlé is working and has given highlighting for water as a part of CSV.

Rural Development: Nestlé prioritized on rural development. To supply raw materials for factories, it often needs to develop dependable sources of quality raw materials. Their development work in rising markets started in the year 1920 when they began building milk factories in Brazil, and required to develop a supply of milk that would be plenty of production needs. Therefore, Nestlé is investing in developing dairy farmers, and have provided free training, micro-loans, and technical assistance to millions of dairy, coffee, cocoa, and vegetable farmers in developing countries. Today it works directly with about 700,000 farmers, making one of the leading private agricultural extension services. It will continue to increase support to farmers and farming communities for the long-term sources of quality raw materials.

\section{CSR ACtIVITIES Of NeStLÉ BANGLADESH LIMITED}

Nestlé Bangladesh limited performs CSR activities in different sectors. Its concentrated major CSR activities in its factory location of Gazipur district. Main CRS activities are-

- Their most important CSR is Nestlé Healthy Kids program, which is creating consciousness about nutrition among school kids so that they can make sure balanced food value in their normal meal.

- Water tank-establishing program to guarantee pure drinking water for the children \& nearby community. Nestle Bangladesh constructed a total of 28 water tanks to ensure safe drinking water in schools. Around 35,309 school students directly benefited from those water tanks. Nestle Bangladesh gave 1,540 students' water education training so that they can learn not only having access to safe water but also wise use of water.

- To treat factory waste water it has a Waste Water Treatment Plant (WWTP). At least $(60 \%)$ is reuse in factory where only $40 \%$ of treated water is discharged to outer. It has a plan to implement 'Zero Waste Discharge' very soon.

- It is careful about sanitation system of rural areas' schools. Nestlé is establishing girls' toilet to reduce the dropout rate of the girls in rural areas. Nestlé Bangladesh has constructed many toilets for the benefit of 8,380 girl's students as they had been observing many female students leave school in the absence of separate toilets.

- Nestlé also has many programs through the Impact Foundation Bangladesh given promoting rural development. Nestlé has implemented a series of nutrition programs 
for mothers club of rural poor women. The company also trained 18,000 women through 600 clubs for eight months including 506 government health officers, 97 Union Parishad female members and 125 community leaders including local respectable persons.

\section{FINDINGS AND RECOMMENDATIONS}

CSR practices of different organizations can contribute to the development of Bangladesh. The corporations can develop the society and community by creating opportunities for employment, providing education, contribution to infrastructural improvement and maintaining a congenial environment. It is more relevant for a country like Bangladesh where the government cannot play a vital role due to unlimited corruptions and lack of resources. Globalization made CSR practice a crucial for Bangladesh businesses. Awareness, eagerness, and sense of the necessity for practicing CSR are becoming more and more prominent, but the overall status of CSR in Bangladesh is still not up to satisfactory level. The food and beverage company, a wholly owned subsidiary of Nestle S.A, received the Standard Chartered-Financial Express Corporate Social Responsibility (CSR) award 2010-11 along with two other reputed companies. Some CSR practices manage by globally across the MNC levels, and several CSR practices differed across the MNC units or were specific to the local functions. The recommendations are:

- A multinational company like Nestlé Bangladesh Limited should diversify their CSR practices and considered the other areas of the society except for health and nutrition.

- It should promote CSR activities to protect the natural environment. It also should perform operations in an ecologically friendly way and ensure sustainable development of the country.

- It would be useful if there were awareness among businesses about corporate social responsibility.

- Not only Gazipur Nestlé Bangladesh Ltd. also should inflate their CSR activities in some other districts even all over the country.

- The government should create a CSR policy and monitor the CSR adoption and performance of MNC's and also give some directions to the MNC's and provide some priority areas for CSR practice.

- Evaluation measures are an integral part of the CSR strategy. Nestlé Bangladesh Limited should set up a separate unit that ensures about CSR plans and actual implementations.

\section{CONCLUSION}

Now a day CSR concept is well familiar to almost all the countries of the world and practicing by many national, international and multinational corporations. It is more imperative in developing nations of the world. The recent advancement of CSR practices is appreciable, but many corporations are doing these for self-interest and profit maximization which is not fair at all. A reputed organization like Nestlé Bangladesh Ltd. must have CSR policies to maintain their status. Accountability and transparency are conducting business in a responsible way. No doubt CSR activities are costly, but it ensures a company's long-term sustainability, as it helps to build corporate icon but people argue that corporations do not use sufficient amount of resources to achieve what they have promised in their CSR policies. 


\section{REFERENCES}

Annual Report, "Nestlé S.A.", Vevey, Switzerland. 2014.

Annual Report, "Nestlé S.A.", Vevey, Switzerland. 2015.

Annual Report, "Nestlé S.A.", Vevey, Switzerland. 2016.

Anupama Mohan, Global corporate social responsibilities management in MNCs, Journal of Business Strategies, Huntsville: Spring 2006. Vol. 23, Iss.1, pg. 9, 24 pgs

Anwar, Zarinah (2005), "Corporate Social Responsibility in Asia Pacific: Malaysia "s Role in Promoting CSR," speech was given at Lex Mundi Asia Pacific Regional Conference, Shangri-la Kuala Lumpur, November 12, 2005.

Ataur R.B, Corporate Social Responsibility Reporting in Developing Countries, Ashgate Publishing, Online version, 2014.

Belal, A.T. (2001), A Study of Corporate Social Disclosures in Bangladesh, Management Auditing Journal 16 (5), 274-289.

Bendell J, Shah R. (2002), Annual Review of Corporate Responsibility. Lifeworth-Greenleaf-New Academy of Business: Sheffield and Bath, UK.

Carroll, A. B. (1979). A three-dimensional conceptual model of corporate social performance. Academy of Management Review 4 (4), 496-503.

Davis, K. \& Blomstrom, R. (1971). Business, society, and environment: Social power and social response. New York: McGraw-Hill.

Davis, K. (1973), "The Case for and against Business Assumption of Social Responsibilities," The Academy of Management Journal, Vol. 16, No. 2, June, pp. 312- 322.

Edward P.M (2009), Why Corporate Social Responsibility? -The Context of Bangladesh, Journal of Ammado Foundation, Online version.

Ghoshal, S. \& Nohria, N. (1989). Internal differentiation within multinational corporations. Strategic Management Journal, 10, 323-337.

Gray et al. (1987), Corporate Social Reporting: Accounting and Accountability, Prentice-Hall International, London.

Hackston D. and Milne M., "Some determinants of social and environmental disclosures in New Zealand companies," Accounting, Auditing \& Accountability Journal, Vol. 9, No.1, pp.77-108, 1996;

Hill, I. (2006), "How Finance Can Help Move CSR up the Agenda," The Cost and Management, ISSN1817-5090 Vol 34, No. 6, November - December, PP 5 - 9.

Hossain, M., Islam, K., Andrew, J., (2006), "Corporate Social and Environmental Disclosure in Developing Countries: Evidence from Bangladesh," cited from http://ro.uow.edu.au/commpapers /179.

HTTP://www.nestlé.com

Imam S, "Corporate Social Performance Reporting in Bangladesh," Managerial Auditing Journal vol. 15, 2000 Pp. 133-141

Jamali, D., Mishak, R. (2007), Corporate Social Responsibility (CSR): Theory and Practice in a Developing Country Context. Journal of Business Ethics 72, 362.

Lantos, G.P. (2001), The boundaries of Strategic Corporate Social Responsibility. Journal of Consumer Marketing 18 (7), 595-630.

Logsdon, J. M. \& Wood, D. J. (2002), Business Citizenship: From Domestic to Global Level of Analysis, Business Ethics Quarterly, 12, 155-187.

Nestlé World, “Nestlé S.A.", Vevey, Switzerland. 2013. 
Preston, L. E. \& Post, J. E. (1975). Private Management and Public Policy, Englewood Cliffs, NJ: Prentice Hall.

Raynard P. and Forstater M. (2002), Corporate Social Responsibility: Implications for Small and Medium Enterprises in Developing Countries, United Nations Industrial Development Organization (UNIDO), Vienna.

Saleh, M. Zulkifli, N. Muhamad, R., (2008), "An Empirical Examination of the Relationship between Corporate Social Responsibility Disclosure and Financial Performance in an Emerging Market," International Journal of Productivity and Performance Management, Vol. 59, No. 3, p.229 - 254.

Sinha, Kamal. (2005), Narayana Murthy: Unofficial Biography (Story), Kamalsinha.com, April 3, http://www.kamalsinha.com/iit/people/narayana-murthy.

Suwaidan, M.S.(2004), "Social responsibility disclosure and corporate characteristics: the case of Jordanian industrial companies," International Journal of Accounting, Auditing and Performance Evaluation, Vol. 1, No. 4, p. 432 - 447.

Wartick S.L. and P. L. Cochran (1985), "The Evolution of the Corporate Social Performance Model", The Academy of Management Review, Vol. 10, No. 4, October, pp. 758- 769.

Wise V. and Ali M. M., "Corporate Governance and Corporate Social Responsibility in Bangladesh with Special Reference to Commercial Banks," AIUB BUS Econ Working Paper Series No 2009.05, 2009.

Wood D. J. \& Pasquero, J. (1997), International Business and Society: A research Agenda for Social Issues Management, An emerging vision (pp. 139-159). Columbia, SC: University of South Carolina Press. 